\title{
塩化銀含有フォトクロミックガラスの暗化と退色
}

\author{
作花済夫・松下和正・神谷寛一 \\ (三重大学 工学部 工業化学科)
}

\section{Darkening and Fading of Photochromic Glass Containing Silver Chloride}

\author{
By \\ Sumio SAKKA, Kazumasa MATUSITA and Kanichi KAMIYA \\ (Department of Industrial Chemistry, Faculty of Engineering, Mie University)
}

\begin{abstract}
Four series of photochromic glasses were prepared by heating a glass having the batch composition $\mathrm{SiO}_{2} 59.5, \mathrm{~B}_{2} \mathrm{O}_{3} 20.6, \mathrm{Al}_{2} \mathrm{O}_{3} 8.9, \mathrm{Na}_{2} \mathrm{O} 4.7, \mathrm{Li}_{2} \mathrm{O} 4.3, \mathrm{Cl} 1.5, \mathrm{Ag} 0.5, \mathrm{CuO}$ $0.015 \%$ in wt. at $570^{\circ} \mathrm{C}$ for $3 \mathrm{hr}$, at $580^{\circ} \mathrm{C}$ for $3 \mathrm{hr}$, at $580^{\circ} \mathrm{C}$ for $8 \mathrm{hr}$ and at $580^{\circ} \mathrm{C}$ for $31 \mathrm{hr}$. The samples of different thicknesses ranging from $0.19 \mathrm{~mm}$ to $2.73 \mathrm{~mm}$ obtained from each series were subjected to optical measurements of darkening and fading. The following results were obtained.

1. The degree of U.V.-induced darkening increased as the sample thickness increased for all series as expected. However, the features of the curves correlating the degree of darkening with the sample thickness varied with the series, namely, with the conditions of high temperature heat treatment required for precipitation of $\mathrm{AgCl}$ particles; the rate of increase in the degree of darkening with increasing thickness of the sample decreased more rapidly as the thickness increased for a series having a large light scattering factor than for a series having a small one. A large scattering factor was caused by large $\mathrm{AgCl}$ particles that was produced by prolonged heat treatment. On the other hand, the degree of darkening of very thin samples did not undergo the effect of the light scattering, but depended only upon the light absorption characteristics of the sample.

2. The rate of fading of U.V.--darkened glasses varied with the thickness of the sample; in general, thinner samples exhibited higher fading rate than thicker ones for glasses subjected to the same heat treatment for $\mathrm{AgCl}$ precipitation.

3. No general relation was found between the degree of darkening and the rate of fading.
\end{abstract}

[Received May 23, 1973]

\section{1. 緒言}

フォトクロミックガラスは，ガラス母体中にハロゲン

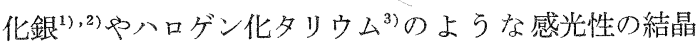
粒子を含み，紫外線や短波長の可視光線の照射によって 暗化し，光の照射を停止すると退色するガラスである。 八ロゲン化銀を含むフォトクロミックガラスの紫外線に よる暗化および退色は, 母体ガラスの組成，析出八ロゲ ン化銀粒子の組成，八口ゲン化銀中の微量不純物，八口 ゲン化銀の析出量, 粒子の大きさ, ガラスの熱処理など によって，複雑な影響を受けることが知られている。こ れらの要因はガラスの光吸収, 光散乱, 八ロゲン化銀の 光分解, 光分解八ロゲン化銀の無色八ロゲン化銀への再 生などの諸性質に影響し, その影響が総括されて, 暗化 能や退色速度がきまると考えられる。
照射光（紫外線など）は，ガラス中の八ロゲン化銀粒 子により一部が散乱され, 必らずしもすべてが暗化に有 效ではないから，一定の厚さをもった実際のフォトク口 ミックガラス試料では, 紫外線の照射側とその反対側で 暗化度や退色速度が異なり，したがって，試料全体の暗 化度や退色速度は, ガラスの厚さの関数であることが推 察される ${ }^{4)}$. この点を考慮して退色速度を物性值として 調べるために，きわめて薄い $(0.09 \mathrm{~mm})$ フォトクロミ ックガラス層を試料として用いた研究5もあるが，ふつ らは 2 3 mm 厚の試料を用いて暗化や退色が調べられ ている ${ }^{6) \sim 8)}$.

本研究では暗化度および退色速度に対する試料の厚さ の影響を検討するために，同一組成のガラスで塩化銀粒 子（実際は必らずしも純粋な塩化銀ではないので，感光 
性粒子と呼ぶべきであるが，簡単のため以下 $\mathrm{AgCl} と$ 呼ぶ）を析出させるための熱処理の時間を変化させて, 紫外部および可視部の分光特性が異なるフォトクロミッ クガラス試料をつくり，フォトクロミック特性の測定を 行なった。さらに， $\mathrm{AgCl}$ 粒子を高温で析出させたの ち，比較的低温 $\left(380^{\circ} \mathrm{C}\right)$ で再加熱した試料についても 同様の測定を行ない比較検討した.

\section{2. 実験}

\section{1 ガラス試料}

使用したガラスは，大阪工業技術試験所の守屋喜郎氏 に組成の選択および熔融を依頼したもので，その組成は 表-1 に示すとおりである。表中のガラス転移点および 熱膨镺係数は, 著者らが石英示差膨脹計により, 測定し て得た值である。ガラスはバッチを白金坩堝に入れて $1480^{\circ} \mathrm{C}$ で 2 時間加熱し, さらに, 1 時間擋拌しながら加 熱したのち，熔融物を鉄板上に流し出して厚さ $7 \sim 8$ $\mathrm{mm}$, 幅約 $50 \mathrm{~mm}$, 長さ約 $200 \mathrm{~mm}$ の板状に成形した のち，空中で放冷して作製されたものである。この板か ら約 $50 \times 30 \mathrm{~mm}$ の寸法の板を 4 個切りとり，塩化銀粒 子を析出させるために, つぎの加熱処理を行なった。

Table 1. Glass used in the experiment.

$\begin{array}{ll}\begin{array}{l}\text { Composition calculated } \\ \text { from the batch (wr\%) }\end{array} & \left\{\begin{array}{l}\mathrm{SiO}_{2} 59.5, \mathrm{~B}_{2} \mathrm{O}_{3} 20.6, \mathrm{Al}_{2} \mathrm{O}_{3} 8.9, \\ \mathrm{Na}_{2} \mathrm{O} 4.7, \mathrm{Li}_{2} \mathrm{O} 4.3, \mathrm{Cl} \mathrm{1.5, \textrm {Ag }} \\ 0.5, \mathrm{CuO} 0.015\end{array}\right. \\ \text { Raw materials used } & \left\{\begin{array}{l}\mathrm{SiO}_{2} \text { (silica sand for optical glass), } \\ \mathrm{H}_{3} \mathrm{BO}, \mathrm{Al}(\mathrm{OH})_{8}, \mathrm{Na}_{2} \mathrm{CO}_{3}, \mathrm{Li}_{2} \mathrm{CO}_{3}, \\ \mathrm{NaCl}, \mathrm{AgNO}, \mathrm{CuO} \text { (reagent grade } \\ \text { chemicals) }\end{array}\right. \\ \begin{array}{c}\text { Glass transition } \\ \text { temperature }\left(T_{g}\right) \\ \begin{array}{c}\text { Linear thermal } \\ \text { expansion coefficient }\end{array}\end{array} & 510^{\circ} \mathrm{C}\end{array}$

$$
\begin{array}{rrrr}
\text { グループA } & \text { シリーズ A } 1 & 570^{\circ} \mathrm{C} & 3 \mathrm{~h} \\
& \text { シリーズ A } 2 & 580^{\circ} \mathrm{C} & 3 \mathrm{~h} \\
& \text { シリーズ A } 3 & 580^{\circ} \mathrm{C} & 8 \mathrm{~h} \\
& \text { シリーズ A } 4 & 580^{\circ} \mathrm{C} & 31 \mathrm{~h}
\end{array}
$$

加熱処理後, 1 枚の板加ら幅約 $9 \mathrm{~mm}$, 長さ約 $30 \mathrm{~mm}$ のたんざく形の片を 5 枚切りとり，それを約 $0.3 \sim 2.7$ $\mathrm{mm}$ の種々の厚さに研削し, 光学研磨を施こして光測定 用の試料を得た。こらして得られた試料は，肉眼的にま ったく均質であった. 熱処理した試料は, 熱処理前のガ ラスにくらべてやや透明度を欠き, とくに, シリーズA3 の試料は, 弱い乳濁を示し, シリーズA 4 は強い乳濁を 示した。

なお，上記のグループAの試料の測定を終ったのち， 一部を比較的低温の $380^{\circ} \mathrm{C}$ で 2 時間加熱し（この加熱 を以後再加熱と呼ぶ), グループ B と名付けて測定を行 なった。すなわち，グループBの処理条件はつぎのとお りである・

$$
\begin{array}{rllll}
\text { グループ B } & \text { シリーズ B } 1 & 570^{\circ} \mathrm{C} & 3 \mathrm{~h}, & 380^{\circ} \mathrm{C} 2 \mathrm{~h} \\
& \text { シリーズ B } 2 & 580^{\circ} \mathrm{C} & 3 \mathrm{~h}, & 380^{\circ} \mathrm{C} 2 \mathrm{~h} \\
& \text { シリーズ B } 3 & 580^{\circ} \mathrm{C} & 8 \mathrm{~h}, & 380^{\circ} \mathrm{C} 2 \mathrm{~h} \\
& \text { シリーズ B } 4 & 580^{\circ} \mathrm{C} & 31 \mathrm{~h}, & 380^{\circ} \mathrm{C} 2 \mathrm{~h}
\end{array}
$$

\section{2 紫外線照射亡光測定}

暗化用の紫外線の照射には, 主として $3600 \AA$ の光を 発生する $8 \mathrm{~W}$ の高圧水銀灯を使用した。試料を水銀灯 の管球（值径 $2 \mathrm{~cm}$ ) の中心から $5 \mathrm{~cm}$ の位置に置き, 室温 $\left(10^{\circ} \sim 11^{\circ} \mathrm{C}\right)$ で 15 分間照射した. 照射試料の光学 密度 (optical density) の測定は，照射を終了したのち 10 秒後に行ない, さらに, 30 秒後, $1,2,5,10$ 分後お よび 20 分後に測定を行なって，退色速度の指標となる 半退色時間を求めた. 光学密度の測定は, 島津ダブルビ 一ム分光光度計 UV-200 老用いて空気を対照として行 なった。

\section{$2.3 \mathrm{X}$ 線测 定}

ガラス中に析出した塩化銀結晶の状態を調べるため に, 理学電機製のX線回折装置を用いて, $\mathrm{AgCl}$ 結晶の (200) ピークの回折線を求めた. $2 \theta$ について $0.1^{\circ}$ 女 てにステップスキャンし，得られたピークの半価幅から Scherrer の式 $L=K \lambda /(\beta \cos \theta)$ を用い, Jones の方法 でインストルメンタル・ブロードニングに対する補正を 行なって, 見掛けの粒径を求めた。また, ピーク面積か ら見掛けの析出結晶量を求めた。

\section{3. 結果}

\section{1 光測定結果の表示法}

図-1 は $\mathrm{AgCl}$ 結晶が析出していない状態のガラス （未処理で，フォトクロミック特性を示さない）（曲線

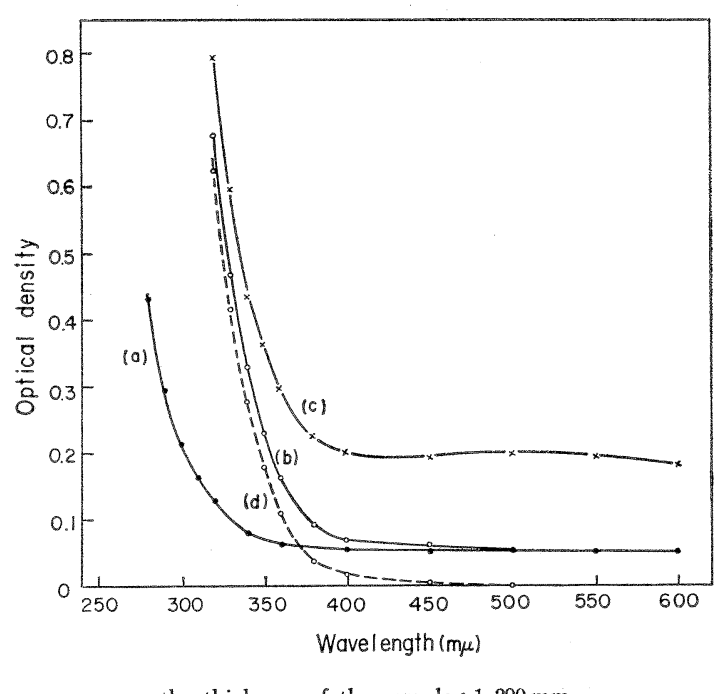

the thickness of the sample: $1.290 \mathrm{~mm}$

Fig. 1 Absorption spectra of (a) original, (b) heat treated and (c) U.V. irradiated glasses. (d) Reflection loss is subtracted from (b). 
a), $570^{\circ} \mathrm{C}$ で 3 時間加熱して $\mathrm{AgCl}$ 結晶を析出させた ガラス（曲線 b) およびこれ比紫外線を照射して暗化さ せた場合（曲線 c) のスペクトルを示したものである. ただし, 曲線 c は照射終了後 30 秒経過したのち, 600 $\mathrm{m} \mu$ から $320 \mathrm{~m} \mu$ まで $100 \mathrm{~m} \mu$ あたり 50 秒の速度で スキャンしてスペクトルを求めたので，実際には波長が 短かくなるにつれて, 長時間退色させた場合の光学密度 が記録されていることになるが，招抒よその概念を得る ために示した。図から， $\mathrm{AgCl}$ 結晶の析出によりフォト クロミズムを示すようになったガラスは, もとのガラス にくらべて, 短波長側で光学密度が大きく（曲線 b $\mathrm{a}$ と比較せよ), $\mathrm{AgCl}$ 結晶を含むガラスは，紫外線照射 によって光学密度が測定波長域の全域にわたって増大寸 る（cをbと比較せよ）ことがわかる.

図-1 の曲線 a, b, c で示される各波長で の光学密度は, ガラスの表面に怙ける光損失 (主として反射による)，バルクのガラスの光 散乱にもとづく損失㧍よびバルクの光吸收か ら成る ${ }^{8)}$ 。このらち, 表面に扔ける損失を差 し引くため, 未照射ガラスの長波長側の光学 密度は，ほぼ表面の損失を表わし，また，表 面の損失の大きさはそれほど波長に依存しな いと仮定して，たとえば，曲線 bの各波長で の光学密度から同じ曲線 b の $600 \mathrm{~m} \mu$ に拧 ける光学密度を差し引いて曲線 d 得た．以 後このような方法で得た值を吸収度（absorbance）と呼ぶ。すなわち, “吸收度”は光 吸収と光散乱の雨者による損失を加えたもの である、照射後の各波長での光学密度（曲線 c) から照射前の光学密度 (曲線 b) を差し 引くと, 紫外線照射による吸収度の増大を表わすスペク トルが得られる。ただし，本研究では，照射による吸収 度の増大は, すべて波長 $550 \mathrm{~m} \mu$ において測定し, “照 射による吸収度の増大”の代わりに, “暗化度”(darkening）といら言葉を使用する。 $I_{0}$ の光が紫外線照射前の ガラスを透過して $I_{\text {non-irrad }}$ となり，紫外線照射後の ガラスを透過して $I_{\mathrm{irrad}}$ となるとすると，暗化度は $\log$ $\left(I_{0} / I_{\text {irrad }}\right)-\log \left(I_{0} / I_{\text {non-irrad }}\right)=\log \left(I_{\text {non-irrad }} / I_{\text {irrad }}\right)$ で表わされる。

\section{$3.2 \mathrm{AgCl}$ 結晶を含むガラスの吸収スペクトル}

グループ A および $\mathrm{B}$ の各シリーズの試料について, $350 \mathrm{~m} \mu$ の波長に怙ける吸収度を厚さの関数として図 -2 に示寸. 若干のばらつきはあるが，各シリーズについて 試料の吸収度は, 原点を通る直線で結ぶことができる。 この直線の勾配から，単位厚さあたりの吸収度を各シリ 一ズについて求めると,

A $1: 0.140 / \mathrm{mm}$, A $2: 0.163 / \mathrm{mm}$ A $3: 0.187 / \mathrm{mm}$, A $4: 0.325 / \mathrm{mm}$

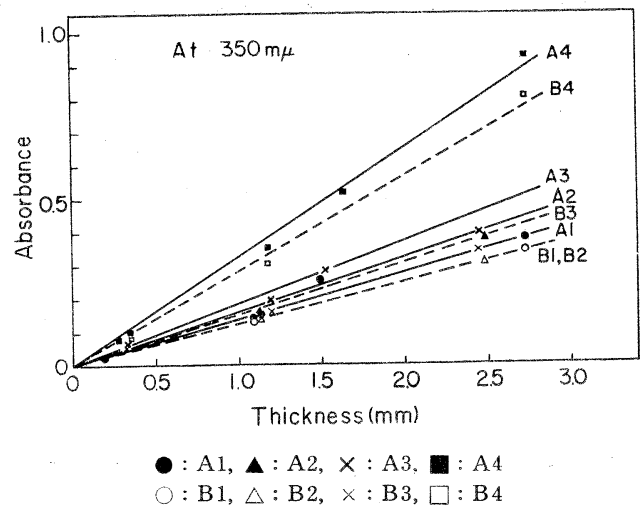

Fig. 2. Absorbance of glasses before U.V. irradiation at $350 \mathrm{~m}$ plotted against the thickness.

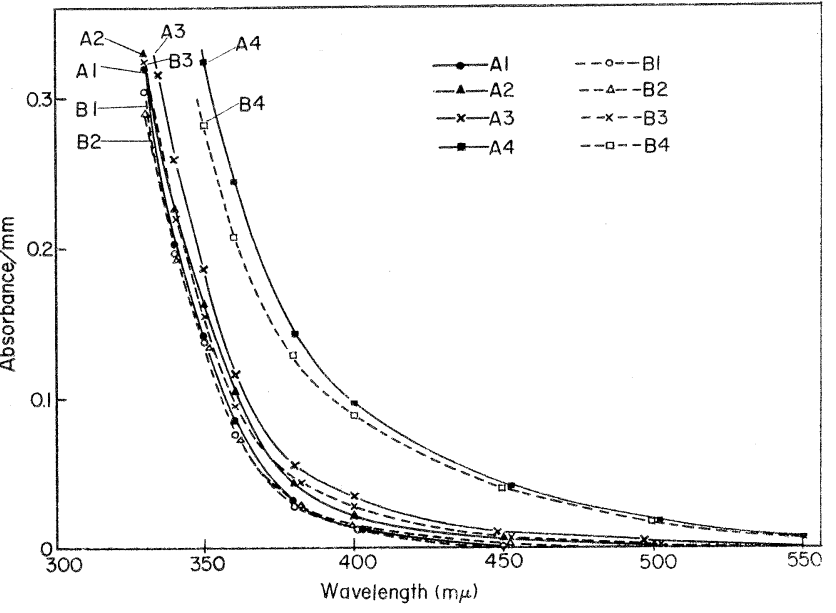

Fig. 3. Absorption spectra of photochromic glasses before U.V. irradiation.
B $1: 0.138 / \mathrm{mm}$,
B $2: 0.138 / \mathrm{mm}$
B $3: 0.155 / \mathrm{mm}$,
B $4: 0.283 / \mathrm{mm}$ であった・

このよらにして各波長について $1 \mathrm{~mm}$ あたりの吸収 度老求め, 各シリーズに対して波長の関数として示した のが図-3 である。図-2 および図-3 からつぎのことが わかる。

(1) 再加熱しないガラス（グループA）の吸収度は, 測定波長域で A $1<\mathrm{A} 2<\mathrm{A} 3<\mathrm{A} 4$ の順に増大する. A 4 の吸収度は他の 3 シリーズにくらべてとくに大き w.

(2) $380^{\circ} \mathrm{C}$ で再加熱すると, A 1, A 2, A 3 および A 4 のいずれのシリーズも吸収度は減少する。すなお ち, 吸収度は, $\mathrm{A} 1>\mathrm{B} 1, \mathrm{~A} 2>\mathrm{B} 2, \mathrm{~A} 3>\mathrm{B} 3, \mathrm{~A} 4$ $>$ B 4 である.

（3）再加熱したガラスの吸収度は，再加熱しない場 合と対応しており， $\mathrm{B} 1 \approx \mathrm{B} 2<\mathrm{B} 3<\mathrm{B} 4$ の順に大き い. B1 とB2 は波長によって吸収度の大小が逆になる 
ことがあるが，差はわずかであり，ほぼ等しいと言え る. B4 の吸収度が，B 1，B 2 および B 3 のそれより とくに大きいことは，グループAの場合（A4 がとくに 大きい）と同様である。

\section{3 紫外線照射による暗化}

紫外線照射による $550 \mathrm{~m} \mu$ での吸収度の増大（すなお ち暗化度）の測定結果を図-4(グループA）および図-5 (グループB) に示す.これらの図は暗化度を厚さの関 数として示したものである。暗化度としては 15 分間紫 外線を照射し, 照射停止後, 10 秒経過したときの值を とってある、図-4 から，各シリーズにおいて，暗化度 は試料の厚さに正比例せず，厚さが增すにつれて暗化度 の厚さによる増大の割合が低くなること，紫外線の吸収 度がとくに大きいもの（シリーズ A4）では，暗化度の

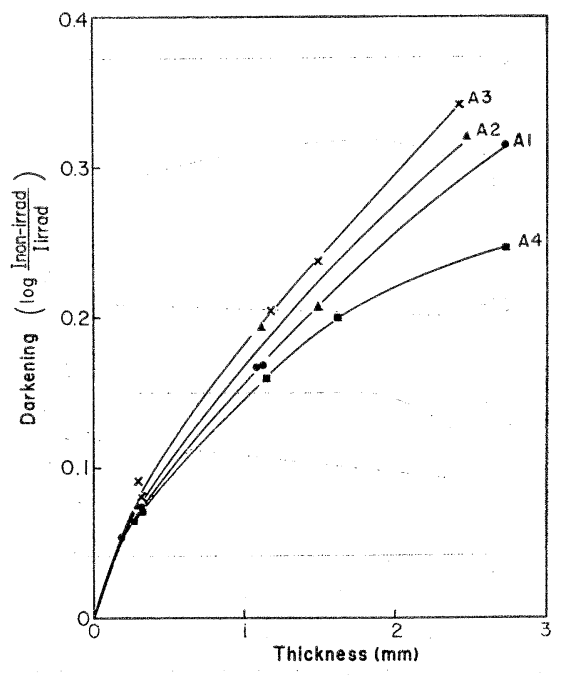

Fig. 4. U.V. induced darkening of glasses without reheating.

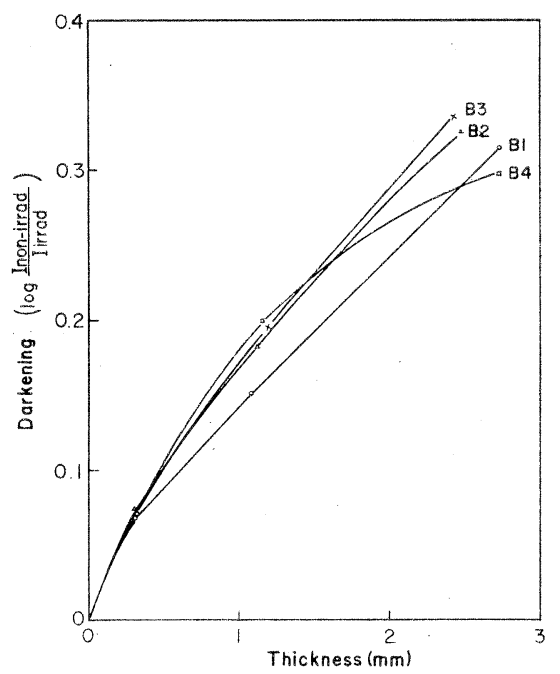

Fig. 5. U.V. induced darkening of glasses reheated at $380^{\circ} \mathrm{C}$
厚さによる増大の割合が, 試料の厚さが増すにつれて, 急速に減少することがわかる．各シリ一ズ間の比較で は, 暗化度は厚い試料においてその差が大きいのに, $0.2 \sim 0.3 \mathrm{~mm}$ の薄い試料では差が小さいことがわかる. たとえば，シリーズA3 とシリーズA4 を比較した場合 (図-4)，厚さが $2.40 \mathrm{~mm}$ のと $\mathrm{A} 3$ の暗化度は 0.340 , A4 の暗化度は 0.238 で, 差は $100 \times(0.340-0.238) /$ $0.340 \doteqdot 33 \%$ であり, $1.2 \mathrm{~mm}$ の厚さでは $100 \times(0.206$ -0.166)/0.206 19\% であるのに対して, $0.2 \mathrm{~mm}$ の厚 さでは差は $100 \times(0.062-0.056) / 0.062 \div 10 \%$ に過ぎ ない。

図 -5 も試料の厚さを $0.3 \mathrm{~mm}$ 程度に薄くすると、シ リーズによって暗化度にあまり差違がないことを示して いる. 図-5 のデータを図-4 のデータと比較すると, $A$ 1 と B 1, A 2 と B 2, A 3 と B 3 の閒にはあまり違い は認められないが，B4 の暗化度は厚い試料ではA4の それにくらべ大きい。たとえば， $2.725 \mathrm{~mm}$ の試料では 暗化度は 0.247 (A4) から 0.298 (B4) に， $1.165 \mathrm{~mm}$ の試料では 0.160 (A4) から 0.200 (B4) に増大してい る.しかし，この場合も薄い試料，たとえば $0.334 \mathrm{~mm}$ の試料では暗化度は $0.072(\mathrm{~A} 4)$ と $0.073(\mathrm{~B} 4)$ でほと んど差はない。

\section{4 暗化試料の退色}

退色速度を調べるために，紫外線を照射したのち 10 秒, 30 秒, 1 分, 2 分, 5 分, 10 分および 20 分後の暗 化度を各試料について測定し，10 秒後の暗化度を 100 として図-6 に例示したよ5な, 暗化度 $(\%)$ と時間の関 係を示す曲線を得た。図一6に示した曲線は, シリーズ B1 に属する 3 種の厚さの異なる試料についての曲線で ある。この曲線加ら退色速度の尺度となる半退色時間 $T_{1 / 2}$, 寸なわち, 暗化度が照射直後の值の $1 / 2$ になるの に要する時間をつぎのようにして求めた。暗化度の測定 は, 実験装置の都合上, 照射を停止して 10 秒経過後に

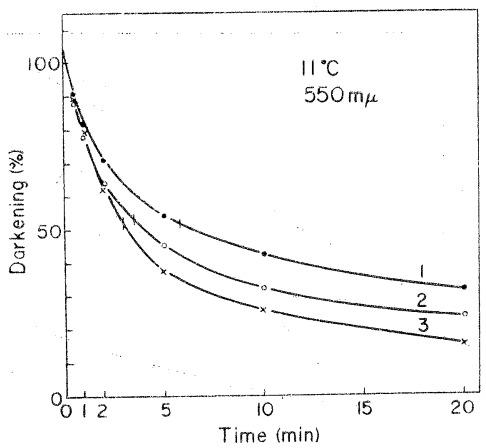

curve $1:$ series $B 1, d=2.730 \mathrm{~mm}, T_{1 / 2}=5.8 \mathrm{~min}$ curve $2:$ series $B 1, d=1.085 \mathrm{~mm}, T_{1 / 2}=3.6 \mathrm{~min}$ curve $3:$ series $\mathrm{B} 1, d=0.320 \mathrm{~mm}, T_{1 / 2}=3.0 \mathrm{~min}$

Fig. 6. Fading of glasses darkened by U.V irradiation. 
行なったので，照射を停止した瞬間の暗化度（\%) を求 めるため, 30 秒後の暗化度と 10 秒後の暗化度を図上で 直線で結んで，時間が 0 分のところまで外插した。たと えば，図-6 の曲線 1 では照射停止の瞬間の暗化度は 104 \%となる，そこで，つぎに曲線 1 で縦軸の值が $52 \%$ に あたる点（曲線上で短かい縦線で示す）に対応する時間 (5.8 分) を求め, こ机を半退色時間 $T_{1 / 2}$ とした。

このようにして求めた半退色時間を図-7(グループA) および図-8 (グループB) に示寸.データに若干のばら つきはあるが，半退色時間は同一シリーズの試料（同じ 熱処理を加えた試料) でも厚さによって変化し，各シリ 一ズに扔いて薄い試料のほうが，厚い陚料よりも半退色 時間が一般に短かい（退色速度が大きい）。同じ厚さに ついてシリーズ間の比較を行ならと,グループAでは熱 処理時間が，中間（8時間）のシリーズ $\mathrm{A} 3$ の半退色時 間は他のシリーズにくらべて著しく長い（退色速度が小 さい）が，グループ Bではシリーズ $\mathrm{B} 1<\mathrm{B} 2<\mathrm{B} 3<$ B4 の順に長い.

図-9 および図-10 はそれぞれグループ A およびグル 一プ $\mathrm{B}$ の試料について，暗化度（照射停止 10 秒後の）

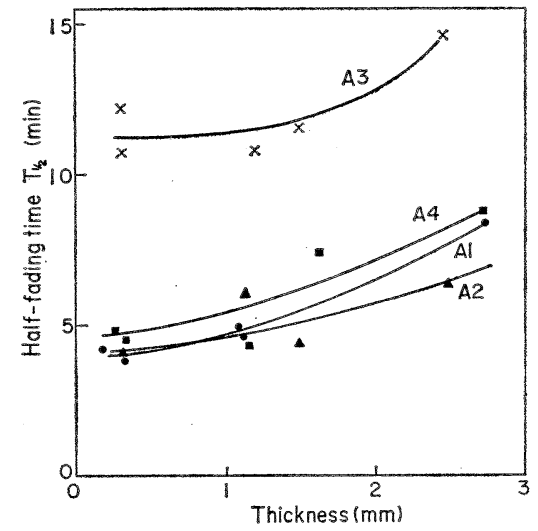

: series A 1, A : series A 2, X: series A 3,

Fig. 7. Half-fading time for glasses of group $A$

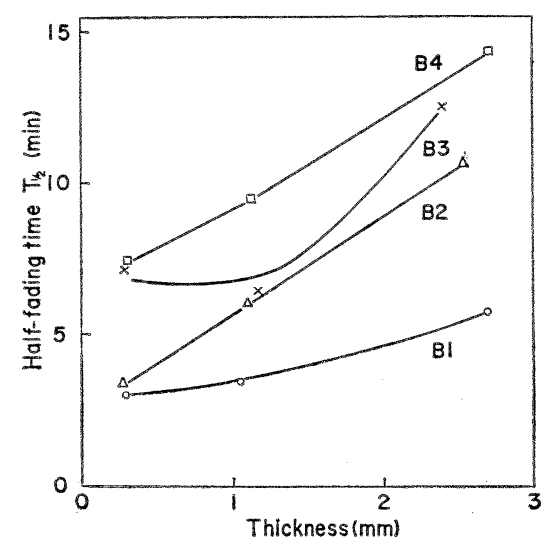

$O$ : series B 1, $\triangle:$ series $B 2, \times$ : series $B 3, \square:$ series $B 4$

Fig. 8. Half-fading time for glasses of group $B$.

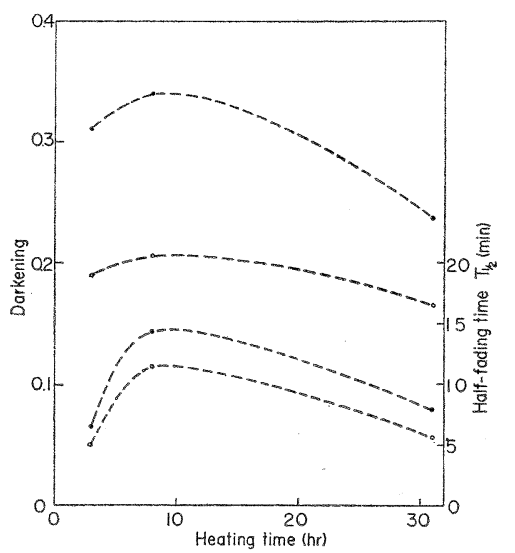

: $2.4 \mathrm{~mm}, \bigcirc 1.2 \mathrm{~mm}$, upper two curves : darkening

Fig. 9. Darkening and half-fading time plotted against time of heat treatment for precipitation of $\mathrm{AgCl}$ crystals for glasses of group A.

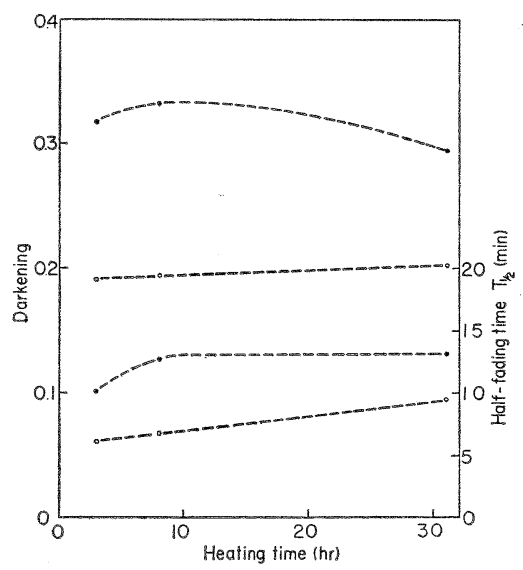

: $2.4 \mathrm{~mm}, O: 1.2 \mathrm{~mm}$, upper two curves : darkening Fig. 10. Darkening and half-fading time plotted against time of heat treatment for precipitation of $\mathrm{AgCl}$ crystals for glasses of group B.

と半退色時間を $\mathrm{AgCl}$ 結晶析出のための加熱時間の関 数として示したものである。これらは上述のように試料 の厚さの関数であるが，代表值として各シリーズから $2.4 \mathrm{~mm}$ 拈よび $1.2 \mathrm{~mm}$ の厚さに対する值を図 -4 〜 8 か ら読みとって示した・シリーズA1 およびB1 は加熱温 度が他のシリーズと異なるので示していない。グループ A (図-9) では，暗化度の大きい 8 時間加熱試料の半退 色時間が長い（退色速度が小さい）といら結果が認めら れるが，グループ B (図-10) では，これと異なってお り，暗化度と退色速度の間に一般的な関係をみいだすこ とは困難であることがわかる。

表-2 は測定結果をまとめて示したものである。

\section{$3.5 \mathrm{AgCl}$ 結晶の粒径}

グループAの各シリーズについて，粉末 X線回折法に よって試料中の $\mathrm{AgCl}$ 結晶の粒径を調べた結果を表-3 に示す. 図-11 は回折図を示したものである.表からシ 


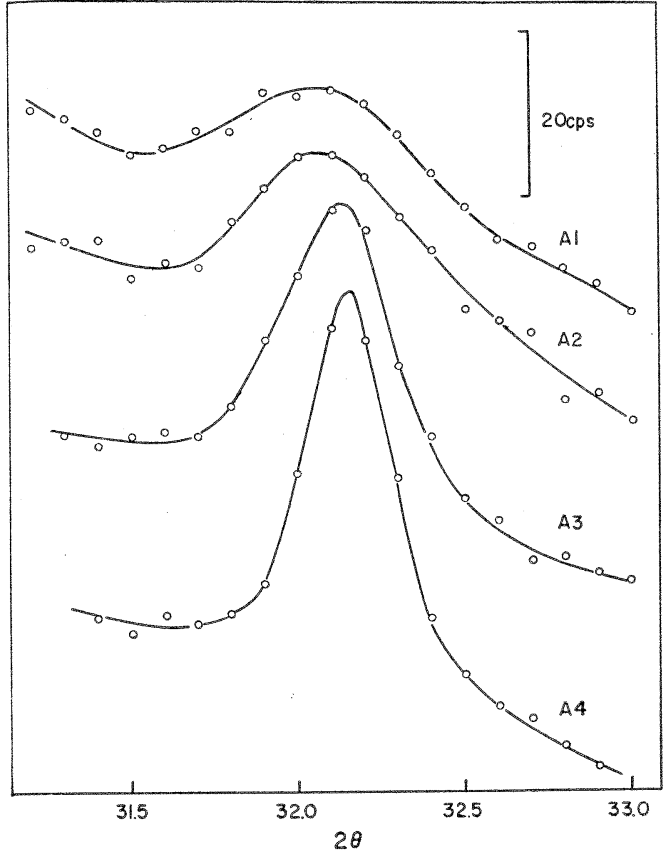

Fig. 11. X-ray diffraction peak of (200) of $\mathrm{AgCl}$ crystals in glasses.
リーズ $\mathrm{A} 1<\mathrm{A} 2<\mathrm{A} 3<\mathrm{A} 4$ の順に析出している $\mathrm{AgCl}$ 結晶の粒径が大きいことがわかる.フォトクロミックガ ラス中の粒子のX線回折については現在詳しく検討して おり，別に発表する予定であるが， $\mathrm{AgCl}$ と考えられて いるものは必らずしも純粋な $\mathrm{AgCl}$ ではなく, $\mathrm{AgCl}$ と $\mathrm{NaCl}$ の固溶体である可能性がある。したがって，加熱 時間による粒子の析出量の変化をX線回折図の面積から 求めることはあまり意味がないと思われる。実際，析出 量を計算してみると, A $1: 0.38 \%$ (重量), A $2: 0.50$ $\%$, A $3: 0.68 \%$, A 4:0.70\% の数值が得られたが, このうち，A3 および A4 の值はバッチとして加えた $\mathrm{Ag}$ のすべてが $\mathrm{AgCl}$ として析出したと仮定して計算 した值 $(0.66 \%)$ よりも大きい，そこで，本研究では析 出量の見掛けの変化は, $\mathrm{AgCl}$ の析出量の变化を表わし

Table 3. Diameter of $\mathrm{AgCl}$ crystals calculated from X-ray diffraction data.

\begin{tabular}{|c|c|c|c|}
\hline \multirow[b]{2}{*}{ Sample } & \multirow{2}{*}{$\begin{array}{l}\text { Heat } \\
\text { treatment }\end{array}$} & \multicolumn{2}{|c|}{ Average diameter } \\
\hline & & $\begin{array}{l}\text { From half-height } \\
\text { width }\end{array}$ & $\begin{array}{l}\text { From integrated } \\
\text { width }\end{array}$ \\
\hline Series A1 & $570^{\circ} \mathrm{C}, \quad 3 \mathrm{hr}$ & $160 \AA$ & $150 \AA$ \\
\hline Series A2 & $580^{\circ} \mathrm{C}, \quad 3 \mathrm{hr}$ & $180 \AA$ & $180 \mathrm{~A}$ \\
\hline Series A3 & $580^{\circ} \mathrm{C}, \quad 8 \mathrm{hr}$ & $310 \AA$ & $270 \AA$ \\
\hline Series A4 & $580^{\circ} \mathrm{C}, 31 \mathrm{hr}$ & $390 \mathrm{~A}$ & $340 \AA$ \\
\hline
\end{tabular}

Table 2. Summary of results.

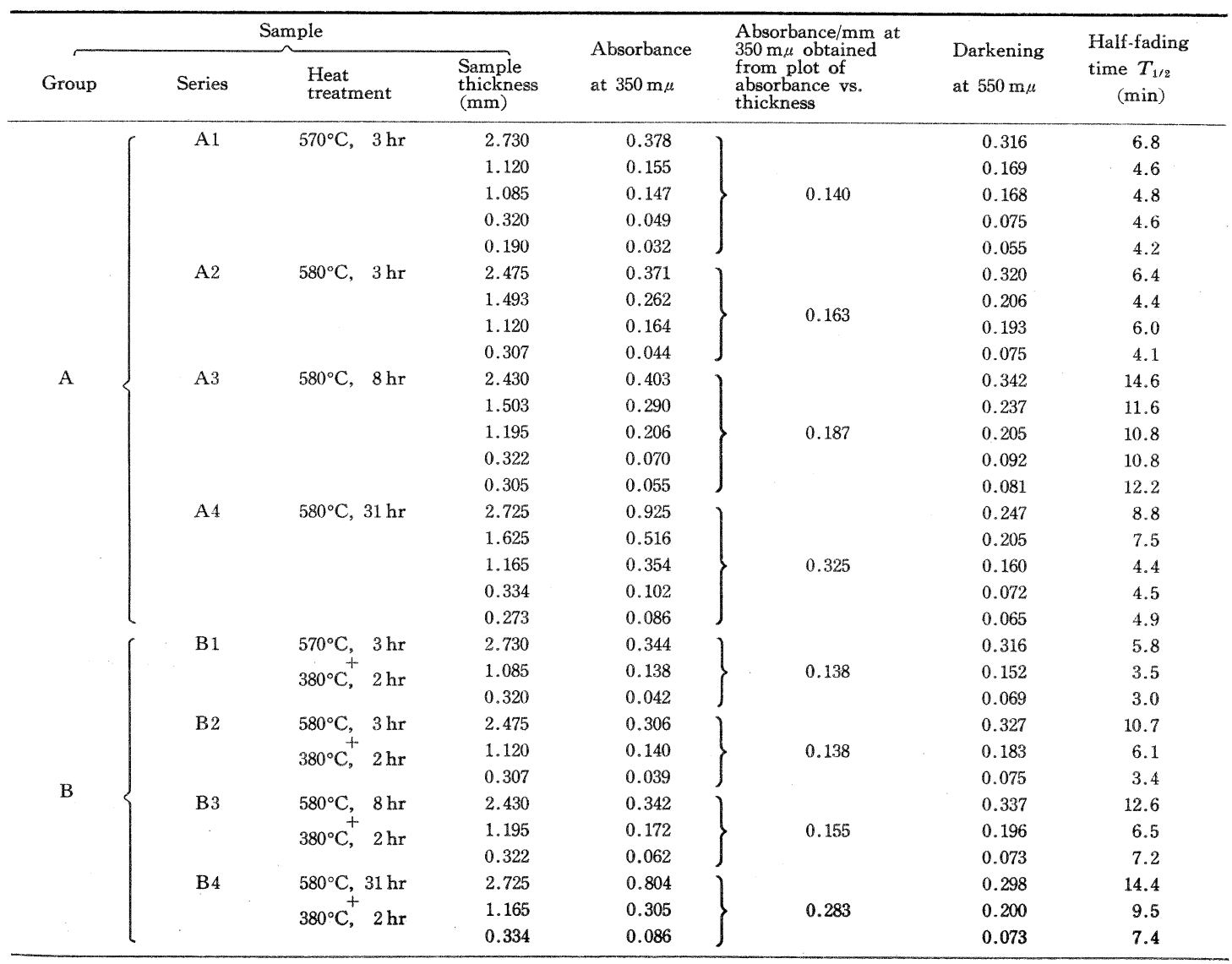


ているものではないと判断し, X線回折のデータは粒径 の変化を知るためにのみ利用することとした．粒径が増 すと, 粒子による光散乱の割合が大きくなることが知ら れているから $580^{\circ} \mathrm{C}$ で加熱した場合, 加熱時間が増す につれて光散乱の割合が增すと言える。

\section{4. 考察}

\section{1 フォトクロミック特性に対する試料の厚さの影 響の工学的意味}

実験結果を要約すると,フォトクロミックガラスの紫 外線照射時の暗化度および照射後の退色の速度は, 試料 の愿さによって変化し，その変化のしかたは同一組成の ガラスであっても, たとえば, $\mathrm{AgCl}$ 結晶析出のための 熱処理の時間によって異なる。このことは希望する特性 のフォトクロミックガラスを求める際に，ガラス組成や $\mathrm{AgCl}$ を析出させるための熱処理条件を問題にするだけ では不十分であることを示している.

暗化度は厚さが $0.3 \mathrm{~mm}$ 程度に薄い試料では, 熱処 理時間によりあまり異ならない，暗化度の厚さによる増 加の割合は, 試料が厚くなるにしたがって減少するが, 加熱時間が長く, 試料の照射前の吸収度がとくに大きい 試料では減少の程度が著しい。したがって, そのような ガラスは試料の厚さを増すことによって暗化度を增すた めには不利である.これはあとで (4.2 項) 述べるよう に, 光の散乱が吸収度を大きくしているからである.

退色速度も試料の厚さの関数であり, 一般に薄い試料 のほうが退色速度が大きかった。しかし，同じ厚さでも 熱処理時間が異なる場 合には, 退色速度も異なってい た。したがって，実用にあたっては退色速度について， ガラス組成, 熱処理時間, 試料の厚さなどを考慮に入れ て測定する必要がある。

\section{2 暗化特性とガラスの光吸収および散乱}

紫外線照射によるガラスの暗化は, ガラス中に析出し ている $\mathrm{AgCl}$ 結晶粒子が, 紫外線を吸収して着色中心 を生じることによっておこる，一方， $\mathrm{AgCl}$ 粒子は紫外 線を吸収するとともに, その粒径や微細構造に応じて光 を散乱する。すなわち，照射された紫外線のうち，一部 は吸収されて暗化に有効にはたらき，一部は散乱されて $\mathrm{AgCl}$ 粒子の暗化にあずからずに損失となる。そこで光 吸収と光散乱の両方がおこるガラスに照射された暗化用 の紫外線 (たとえば, $400 \mathrm{~m} \mu$ より短波長の光が $\mathrm{AgCl}$ ガラスを暗化させる $\left.{ }^{1)}\right)$ のちち，吸収されるものの量が 試料の厚さによってどのよらに変化するかをまず計算 し，それに基づいてガラスの厚さによる暗化度の変化を 考察する.

4.2.1 紫外線の吸収強度試料の厚さ方向の距離 を $t$ で表わし, 紫外線の照射側の表面を $t=0$ にとる. $t=t$ の位置で $d t$ の厚さで吸収される紫外線の量を $d I_{a b}$, 散乱される紫外線の量を $d I_{s c}$ とすると,

$$
\begin{aligned}
& d I_{a b} / I=k d t . \cdots \\
& d I_{s c} / I=\alpha d t .
\end{aligned}
$$

実際には散乱はあらゆる方向におこるため, 散乱され る紫外線のすべてが損失となるわけではないが, ここで は はによって損失となるような散乱を表わし，(2) 式が 成立すると仮定する。

紫外線の強度の変化は, 吸収と散乱の両方によってお こるから，

$$
\begin{aligned}
& d I_{a b}+d I_{s c}=-d I . \\
& d I / I=-(k+\alpha) d t .
\end{aligned}
$$

これらの式で, $k$ は吸収係数, $\alpha$ は散乱係数, $I$ は $t$ $=t$ の位置に抢ける紫外線の強度, $-d I$ は $d t$ の愿さ のガラスによる紫外線の強度の減少量である.

（4）式を積分し， $t=0$ における紫外線強度を $I_{0}$ とす ると,

$$
I=I_{0} \exp \{-(k+\alpha) t\}
$$

この式は $I_{0}$ の強度の光が厚さ $t$ の媒質を通過したの ちにIの強度の光となることを示すものである.

(5) 式の $I$ を(1) 式に代人すると,

$$
d I_{a b}=k I_{0} \exp \{-(k+\alpha) t\} d t .
$$

この式の両辺を $t=0\left(I_{a b}=0\right)$ から $t=t \quad\left(I_{a b}=I_{a b}\right)$ まで積分すると，

$$
I_{a b}=\frac{k}{k+\alpha} I_{0}[1-\exp \{-(k+\alpha) t\}]
$$

$I_{a b}$ は $t$ なる厚さのガラスによって吸収される紫外線 の強度である.散乱によって失わ机る紫外線の量は同様 にして

$$
I_{s c}=\frac{\alpha}{k+\alpha} I_{0}[1-\exp \{-(k+\alpha) t\}] \ldots
$$

(7) 式によれば, 厚さ $t$ のガラスが吸収する紫外線の 量 $I_{a b}$ は, $t$ の関数として図-12 のように表わされる.

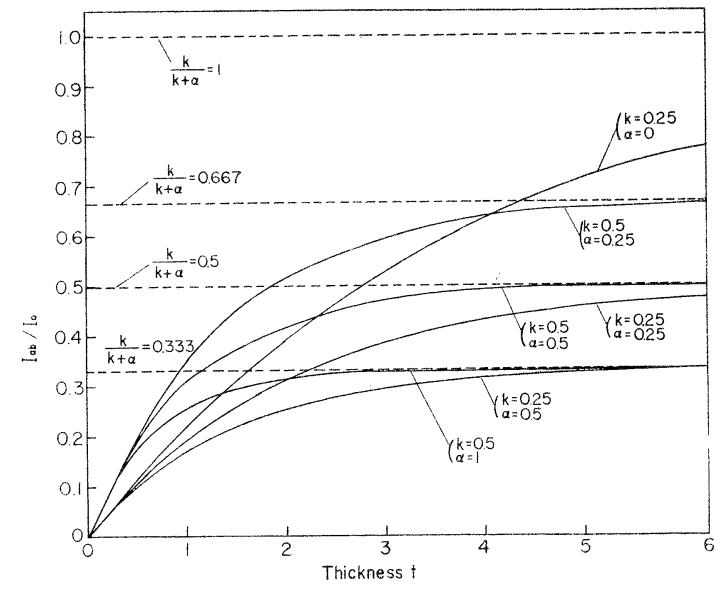

Fig. 12. Schematic representation of the absorbed light intensity as a function of the thickness for various absorption and scattering coefficients. 
(7) 式で $t \rightarrow \infty$ とおくと, 厚さがきわめて大きいとき の $I_{a b}$ が得られる。

$$
I_{a b} \fallingdotseq \frac{k}{k+\alpha} I_{0} \quad(t \text { 大 })
$$

厚さ $t$ が小さいときには, $\exp \{-(k+\alpha) t\} \fallingdotseq 1-(k+$ a) $t$ の近似式を用いて (7) 式から次式が得られる.

$$
I_{a b} \fallingdotseq k I_{0} t \quad(t \text { 小 })
$$

この式は $t$ が小さいときに吸収される紫外線の量は, 吸收係数 $k$ の夕に依存し, 散乱係数 $\alpha$ の大きさにはよ らないことを示している。

\section{2 .2 照射時に吸収される紫外線の量と暗化特性の} 比皎 フォトクロミックガラスの暗化は, 吸収された 紫外線によって着色中心が生成することによっておこ り, 暗化度は存在する着色中心の濃度に比例する.フォ トクロミックガラスでは一定強度の紫外線を照射した場 合, 時間が経過すると, 着色中心の生成と崩壊の速度が 同一になって存在する着色中心の濃度が平衡に達し, し たがって, 暗化度も平衡に達する ${ }^{1,2)}$ 。著者らが測定す る暗化度は, この平衡暗化度に近く, また, 平衡暗化度 はガラスに吸收される（散乱損失を除いたもの）紫外線 強度に比例すると仮定すると, 暗化度は $I_{a b}$ に比例し, 暗化度と試料厚さ $t$ の関係は, 困-12 の曲線と似た形 状を示すはずである. 実際に測定によって得られた暗化 度と厚さの関係を示す図-4 の曲線は，図-12 の曲線と その形状が類似している. すなわち， $t$ が増すにつれ て, ある一定の值に近づく様子が認められ， $\mathrm{AgCl}$ の粒 径が大きいために散乱が大きいと推察されるA4 シリ一 ズでは, 比較的急速に他のシリーズより低いレベルの一 定值に近づくようである。また，Aグループの 4 つのシ リーズを比較した場合，シリーズによって吸収係数 $k$ の 值にあまり大きい差がないと仮定すると, 薄い試料の暗 化挙動をうまく説明することができる. すなわち， $t$ が 小さい場合には，暗化度はあまりシリーズによって違っ ておらず (図-4)，これは $t$ が小さい場合に照射された 紫外線のうち, 試料に吸収されるものの強度は吸収係数 $k$ の值だけできまり, 散乱の影響は大らないといら図一 12 の曲線の傾向と一致している。

\section{3 塩化銀の粒径および熱処理の効果}

前項で諸種の仮定を行なって暗化の過程圭単純化し， きわめて薄い試料では暗化度は $k$ の夕に依存し, 厚い斌 料では暗化度は $k$ と $\alpha$ によってきまると考えた. $k$ と めのうち， ※は $\mathrm{AgCl}$ の粒径により大きく変ることが 明らかである。

図-2 および図-3 からわかるように, $380^{\circ} \mathrm{C}$ での再加 熱によりいずれのシリーズについても試料の紫外部の吸 収度（光吸収+散乱損失）は多少とも減少している。た とえば, 図-4 の曲線 A 4 と図-5 の曲線 B4 を比較して 薄い試料では暗化度が似ており, 愿い試料ではかなりの
差があることから，この吸収度の減少は $k$ の変化による よりもむしろ の滅少を表わしていると考えられる。 $380^{\circ} \mathrm{C}$ の再加熱により 1 個の $\mathrm{AgCl}$ 粒子の大きさが大 きく変化するとは思われないから，このめの変化は 1 個 の粒子内での状態が変化したために抽ったのである 5 .

以上要するに，薄い試料（たとえば $0.3 \mathrm{~mm}$ 以下） で暗化度を測定すれば, $\mathrm{AgCl}$ 粒子による有効な波長領 域の紫外線の吸収 $(k)$ 方効果的にあらわれ, 厚い試料 (たとえば 1〜2 $\mathrm{mm}$ 以上) で測定を行なえば， $\mathrm{AgCl}$ 粒子の光散乱 $(\alpha)$ の影響が加わることを示した。ただ し, ここで注意しなければならないのは，薄い，厚いの 区別は，試料の厚さの絶対值だけによるものでなく，有 効紫外光の吸収と散乱の大きさの割合によって異なり, 散乱の割合が大きい試料ほどその影響が薄い試料であら われることである。

なお，図-7〜10 に示した半退色時間の試料厚，加熱 時間, $380^{\circ} \mathrm{C}$ での再加熱の有無による変化に関し, 現在 説明を加えることは困難であるが，このような現象がお こることは，諸種の条件によって $\mathrm{AgCl}$ 粒子の状態が 微妙に変化することを示していると思われる.

\section{5. 総 括}

バッチ組成が $\mathrm{SiO}_{2} 59.5, \mathrm{~B}_{2} \mathrm{O}_{3} \quad 20.6, \mathrm{Al}_{2} \mathrm{O}_{3}$ 8.9, $\mathrm{Na}_{2} \mathrm{O} 4.7, \mathrm{Li}_{2} \mathrm{O} 4.3, \mathrm{Cl} 1.5, \mathrm{Ag} 0.5, \mathrm{CuO} 0.015 \%$ (重量)のガラスに種々の熱処理 $\left(570^{\circ} \mathrm{C} 3\right.$ 時間, $580^{\circ} \mathrm{C}$ 3 時間, $580^{\circ} \mathrm{C} 8$ 時間, $580^{\circ} \mathrm{C} 31$ 時間) を加えて $\mathrm{AgCl}$ 粒子を析出させ, 得られたフォトクロミックガラスから $0.19 \sim 2.73 \mathrm{~mm}$ の範囲で厭さの異なる試料をつくって, その吸収度 (吸収スペクトル), 暗化度（紫外線照射に よる吸収度の増加), 半退色時閒を測定し, 以下の結果 㐋得た。

1. ガラスの暗化度は試料の厚さが増すにつれて増大 するが，その増大の割合はガラスの高温熱処理 $(\mathrm{AgCl}$ 粒子を析出させるための熱処理）の条件によって異なる ことがわかった。すなわち，ガラスの熱処理の時間が長 くて析出している $\mathrm{AgCl}$ 粒子が大きく, そのため着色 中心の生成に有效な紫外光の散乱が大きい場合には, 加 熱時間が短かくて散乱が小さい場合にくらべて, 試料の 厚さの増大にともなら暗化度の増大の割合が急速に低下 した。これに対し, 非常に薄い試料ではガラスの暗化度 は散乱の影響を受けず，したがって，紫外線の吸收特性 が同一なら散乱のいかんにかかわらず，暗化度は同一で あるとの推察が得られた.

2. 紫外線照射によって暗化したガラスの半退色時間 （退色速度の尺度）は，多少とも試料の厚さの影響を受 け, 同一の高温熱処理を施したガラスについて, 一般に 薄い試料ほど半退色時間が短かい, 寸なわち, 退色速度 
が大きいことがわかった。

3. 高温熱処理の時間によって退色速度は変化した が，実験に用いたガラスでは，X線回折図から計算した $\mathrm{AgCl}$ の粒径が, 約 $300 \AA$ となる熱処理条件 $\left(580^{\circ} \mathrm{C}\right.$ 8 時間) のときに退色速度がもっとも小さかった. 暗化 度は薄い試料では, 高温熱処理の条件によってあまり変 化しなかったので厚い試料で比較したが，上記の熱処理 条件のときにもっとも大きかった.

4. 高温熱処理により $\mathrm{AgCl}$ を析出させたガラスを 比較的低温の $380^{\circ} \mathrm{C}$ で再加熱すると, 暗化度および退 色速度はいくらか変化したが，暗化度と試料厚の関係に ついての 1.に述べた結論はほぼ成立した。ただし，退 色速度が小さい場合に, 暗化度が大きいという2。の関 係は,この場合には認められず，暗化度と退色速度の間

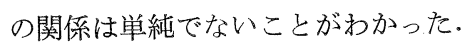

謝辞本研究用のガラス試料をご提供下さった大阪工業 技術試験所の等屋喜郎博士, 光測定に協力された三重大学 工 学部の今井治子氏に感謝の意を表します.

\section{文献}

1) W.H. Armistead, S.D. Stookey, Science 144, 150 (1964).

2) G.P. Smith, J. Mat. Sci. 2, 139 (1967).

3) S. Sakka, J.D. Mackenzie, J. Am. Ceram. Soc. 55, 553 (1972).

4) G.K. Megla, Appl. Optics. 5 [6] 945 (1966).

5) R.J. Araujo, "Reactivity of Solids", ed. J.W. Mitchell et al, Wiley-Interscience (1969) p. 707.

6）田中博史，窐協 80 [6] 219-26 (1972).

7）守屋喜郎，ガラス技術の新しい方向（大工試成果発表会 資料) (1972) p. 13-22.

8) T. Maki, M. Tashiro, Bull. Inst. Chem. Res., Kyoto Univ. 50 [6] 621 (1972).

(5/23/1973 受付) 